\title{
Salicylic acid as attenuator of drought stress on germination and initial development of sesame
}

\author{
Adriana C. da Silva ${ }^{1}$, Janivan F. Suassuna ${ }^{2}$, Alberto S. de Melo ${ }^{1}$, \\ Rayssa R. Costa ${ }^{1}$, Wellerson L. de Andrade ${ }^{1} \&$ Duval C. da Silva ${ }^{1}$ \\ ${ }^{1}$ Universidade Estadual da Paraíba/Programa de Pós-Graduação em Ciências Agrárias. Campina Grande, PB. E-mail: dricaconceicao@hotmail.com; \\ alberto@uepb.edu.br; rayssa.rc@outlook.com; welerson.rocker@hotmail.com; duvalchagas@hotmail.com \\ ${ }^{2}$ Universidade Federal do Amapá/Educação do Campo. Mazagão, AP. E-mail:jf.su@hotmail.com (Corresponding author)
}

\section{Key words:}

Sesamum indicum L. drought

tolerance promotion

\begin{abstract}
A B S T R A C T
Sesame is an important crop in Northeast Brazil, where climate conditions require adapted genotypes and alternatives for plant defense against drought. This study aimed to evaluate the salicylic acid as drought attenuator in sesame genotypes. The experiment evaluated six genotypes (BRS Seda, CNPA-G2, CNPA-G3, CNPA-G4, LAG-Branquinha and LAGPretinha), five osmotic potentials $(0,-0.2,-0.4,-0.6$ and $-0.8 \mathrm{MPa})$ and three seed treatments (soaking in distilled water, in salicylic acid and no treatment). CNPA-G4 is tolerant to drought in the germination stage. Salicylic acid at $10^{-5} \mathrm{M}$ induced tolerance to drought stress in sesame, but it is necessary to test other concentrations.
\end{abstract}

\section{Palavras-chave:}

Sesamum indicum L. déficit hídrico promoção de tolerância

\section{Ácido salicílico como atenuador de estresse hídrico na germinação e no desenvolvimento inicial de gergelim}

\begin{abstract}
R E S U M O
O gergelim é uma importante cultura no Nordeste brasileiro, cujas condições de semiaridez exigem genótipos adaptados, além de alternativas para defesa da planta contra a seca. Assim, objetivou-se avaliar o ácido salicílico como atenuador do estresse hídrico em genótipos de gergelim. Foram estudados seis genótipos (BRS Seda, CNPA-G2, CNPA-G3, CNPA-G4, LAG-Branquinha e LAG-Pretinha); cinco potenciais osmóticos $(0 ;-0,2 ;-0,4 ;-0,6$ e - $-0,8$ $\mathrm{MPa}$ ) e três tratamentos das sementes (pré-embebição em água destilada; em ácido salicílico e sem embebição). O genótipo CNPA-G4 possui elevada capacidade de tolerância ao déficit hídrico, na fase de germinação. $\mathrm{O}$ ácido salicílico a $10^{-5} \mathrm{M}$ induziu tolerância ao estresse hídrico em gergelim, porém se necessita testar outras concentrações.
\end{abstract}




\section{INTRODUCTION}

For its tolerance to drought stress, sesame (Sesamum indicum L.) is an alternative crop for exploitation in small rural communities, representing a very important economic support for the northeastern semi-arid region (Bezerra et al., 2010). However, water deficit is common in this region and has compromised the development and yield of most agricultural crops under rainfed regime, including sesame, despite its good capacity of adaptation to drought (Bezerra et al., 2010).

According to Bezerra et al. (2010), although sesame has characteristics of tolerance and advantages for the cultivation in semi-arid regions, most of its development stages are affected by drought stress, varying the specific cellular responses depending on the plant organ, development stage, genotype, severity and duration of the stress, and one of the most relevant periods for plant survival is from germination until the establishment of the seedlings.

This fact leads to the search for forms of attenuation of the adverse effects of abiotic stress, such as the salicylic acid (SA), since its exogenous application in plants has been studied, testing its action as attenuator of these effects. SA is a phenolic compound originated from the secondary metabolism, an important regulator of physiological processes in the plant, such as photosynthesis. It is considered as a potential enzymatic antioxidant agent, related to the defense of the plant under stress conditions (Noreen et al., 2009).

Therefore, given the potential of sesame in semi-arid regions, it is notorious the necessity of genetic materials more adapted to these environments and alternatives that assist the tolerance to drought stress and improve its cultivation. Thus, this study aimed to evaluate the salicylic acid as attenuator of drought stress in the initial development of sesame.

\section{Material ANd Methods}

The experiment was carried out at the Laboratory of Ecophysiology of Cultivated Plants (ECOLAB), of the State University of Paraíba (UEPB - Campus I), Campina Grande$\mathrm{PB}$, Brazil, in BOD chamber, during 15 days. The experiment evaluated six sesame genotypes (BRS Seda, CNPA-G2, CNPA-G3, CNPA-G4, LAG-Branquinha and LAG-Pretinha); five osmotic potentials of the substrate $(0.0,-0.2,-0.4,-0.6$ and $-0.8 \mathrm{MPa}$ ) and three seed treatments (seeds pre-soaked in salicylic acid; seeds pre-soaked in distilled water and seeds without soaking).

The sesame genotypes indicated for cultivation in the Northeast region were provided by the Embrapa Cotton, Campina Grande-PB. The levels of osmotic potential, except $0.0 \mathrm{MPa}$ in which distilled water was used, were induced using polyethylene glycol 6000 (PEG 6000), according to Michel \& Kaufmann (1973):

$$
\begin{aligned}
\psi_{\text {os }} & =\left(1.18 \times 10^{-2}\right) \mathrm{C}-\left(1.18 \times 10^{-4}\right) \mathrm{C}^{2}+ \\
& +\left(2.67 \times 10^{-4}\right) \mathrm{CT}+\left(8.39 \times 10^{-7}\right) \mathrm{C}^{2} \mathrm{~T}
\end{aligned}
$$

where:

$\Psi_{\text {os }} \quad$ - osmotic potential (bar);
C - concentration of the osmotic agent (g of PEG 6000 $\mathrm{L}^{-1}$ of $\mathrm{H}_{2} \mathrm{O}$ ); and,

$\mathrm{T}$ - temperature $\left({ }^{\circ} \mathrm{C}\right)$.

The seeds were separated into three lots; the first one was soaked in $10^{-5} \mathrm{M}$ SA solution and the second one was soaked in distilled water (DW), both for $8 \mathrm{~h}$, avoiding germination before sowing. The seeds were placed on paper towel moistened with the respective solutions and arranged in roll. The third lot was not subjected to soaking (WS). After selection, the seeds were treated with fungicide from the dicarboximide chemical group, with captan as the active principle ( $240 \mathrm{~g} \mathrm{~kg}^{-1}$ of seeds).

The test of germination was conducted in Gerbox boxes $(11.0 \times 11.0 \times 3.5 \mathrm{~cm})$, in a completely randomized experimental design, with four replicates of 50 seeds. The seeds were distributed on two Germitest paper sheets and covered with a third sheet, all moistened with the solutions of different osmotic tensions, at the proportion of 2.5 times the weight of the paper. The temperature of the chamber was alternated between 25 and $30{ }^{\circ} \mathrm{C}$, the ideal temperature range for the development of the crop, including for germination (Arriel et al., 2009). The photoperiod was $12 \mathrm{~h}$ during the entire test.

On the sixth day after experiment installation, the percentage of germinated seeds (PG) (\%) was determined (Brasil, 2009). In addition, data of count of germination were used to determine the germination speed index (GSI) (Maguire, 1962), using Eqs. 2 and 3, respectively:

$$
\begin{gathered}
\mathrm{PG}(\%)=\left(\frac{\sum \mathrm{ni}}{\mathrm{N}}\right) \times 100 \\
\mathrm{GSI}=\frac{\mathrm{G} 1}{\mathrm{~N} 1}+\frac{\mathrm{G} 2}{\mathrm{~N} 2}+\ldots+\frac{\mathrm{Gn}}{\mathrm{Nn}}
\end{gathered}
$$

where:

PG - percentage of germinated seeds;

$\Sigma$ ni - total number of germinated seeds;

$\mathrm{N}$ - number of seeds placed to germinate;

GSI - germination speed index;

G1, G2, Gn - number of germinated seeds in the first, second and last counts; and,

$\mathrm{N} 1, \mathrm{~N} 2$ and Nn - days from sowing to the first, second and last counts.

GSI was calculated based on daily counts of germinated seeds, which stopped when germination stabilized (Brasil, 2009; Maguire, 1962). Shoot length (SL) of the seedlings was measured 15 days after installation, by separating ten normal seedlings (normal and proportional development of the radicle and shoots) of each treatment, for the measurement of the distance between the apex of the shoots and the base.

For the quantification of the activity of the enzymes catalase (CAT) and superoxide dismutase (SOD), $50 \mathrm{mg}$ of fresh material (radicle and shoots) were collected, macerated with polyvinylpolypyrrolidone (PVPP, 5\%) and homogenized in 3 $\mathrm{mL}$ of the extraction buffer $(100 \mathrm{mM}$ potassium phosphate 
(pH 7.0), 0.1 mM EDTA), The homogenate was centrifuged at $13,000 \times \mathrm{G}$ for $20 \mathrm{~min}$ at $4^{\circ} \mathrm{C}$ and the supernatant was transferred to $1.5 \mathrm{~mL}$ microtubes and frozen at $-18^{\circ} \mathrm{C}$ for a mean time of 15 days until the determinations.

CAT activity, expressed in mmol of $\mathrm{H}_{2} \mathrm{O}_{2} \mathrm{~min}^{-1} \mathrm{mg}^{-1}$ of protein, was determined according to Beers Júnior \& Sizer (1952) and the $\mathrm{H}_{2} \mathrm{O}_{2}$ consumption was estimated by the decrease in the absorbance at $240 \mathrm{~nm}$. The reaction medium $(3 \mathrm{~mL})$ consisted of the buffer $50 \mathrm{mM}$ potassium phosphate ( $\mathrm{pH} 7.0$ ), $0.1 \mathrm{mM}$ EDTA and $50 \mu \mathrm{L}$ of the plant extract. 2.27 $\mu \mathrm{L}$ of $\mathrm{H}_{2} \mathrm{O}_{2}(30 \%)$ were added to the enzymatic plant extract and, immediately after, readings were taken in quartz cuvettes, during $1 \mathrm{~min}$ of reaction, every $10 \mathrm{~s}$. Readings of the reaction solution without the enzymatic extract (reagent blank) were taken and the difference in absorbance $(\triangle \mathrm{A} 240)$ was multiplied by the molar extinction coefficient of $36 \mathrm{~mol} \mathrm{~L}^{-1} \mathrm{~cm}^{-1}$ (Anderson et al., 1995).

For SOD quantification, $100 \mu \mathrm{L}$ aliquots of plant extract were transferred to a reaction medium containing the buffer $100 \mathrm{mM}$ potassium phosphate ( $\mathrm{pH} 7.8$ ), $156 \mu \mathrm{L}$ of methionine (14 mM), $30 \mu \mathrm{L}$ of EDTA $(0.1 \mathrm{mM})$ and $45 \mu \mathrm{L}$ of NBT $(75 \mathrm{mM})$ (Giannopolitis \& Ries, 1977). The reaction was initiated by the addition of $60 \mu \mathrm{L}$ of riboflavin $(2 \mu \mathrm{M})$. Subsequently, the tubes were transferred to a wooden box illuminated by fluorescent lamps totaling 60 watts (luminous flow of 4200 lumens min $^{-1}$ ) during $15 \mathrm{~min}$. Readings were taken in triplicate, at wavelength of $560 \mathrm{~nm}$. All readings (CAT and SOD) were performed in spectrophotometer, model UV-VIS 190 to 1100.

The data were evaluated through analysis of variance ( $F$ test at 0.05 probability level) and the test of comparison of means (Tukey, $\mathrm{p} \leq 0.05$ ); in cases of significance, by the F test.

\section{Results AND Discussion}

The percentage of sesame germination decreased with the osmotic stress in the substrate (Figure 1). In 'BRS Seda', there was high germination (65\%) at the potential of $0.0 \mathrm{MPa}$ and $38.7 \%$ at the potential of $-0.4 \mathrm{MPa}$ in the treatment of soaking with salicylic acid (SA), but there was no germination at the potential of $-0.8 \mathrm{MPa}$ (Figure 1A). The high stress prevented seed hydration and the beginning of metabolic reactions for the occurrence of the reactions that induce the formation of the growing organs (Dousseau et al., 2008), such as cell division, expansion and differentiation.

The 'CNPA-G4' must be highlighted, which showed high germination at all tested osmotic potentials, being more tolerant to drought stress in the stage of germination. At the potential of -0.4 MPa, seeds soaked in DW and SA showed germination of 98.75 and 95\%, respectively (Figure 1D).

At negative osmotic potentials, 'LAG-Branquinha' obtained expressive germination in SA at -0.2 and $-0.4 \mathrm{MPa}$, with 61.25 and $38.75 \%$ of germination, although there was difference between SA and DW at $-0.4 \mathrm{MPa}$ (Figure $1 \mathrm{E}$ ), which may indicate the induction of production of proteins of tolerance to the stress by the SA (Carvalho et al., 2007).

There was a reduction in GSI in all genotypes as the osmotic potential decreased (Figure 2). For 'CNPA-G4' and 'LAG-Pretinha', the reduction occurred only from the lowest potentials $(-0.6$ and $-0.8 \mathrm{MPa})$, regardless of the seed treatment (Figures 2D and 2F), while in 'LAG-Branquinha' the GSI decreased from -0.2 MPa (Figure 2E). In 'CNPA-G4', the means were high $(22.76,22.68$ and 21.39) in SA until the potential of $-0.4 \mathrm{MPa}$. Such effect was similar to those found by Silva et al. (2014) in watermelon seeds, with highest GSI in seeds treated with SA.
A. 'BRS-Seda' 口DW $\square$ SA $\square$ WS

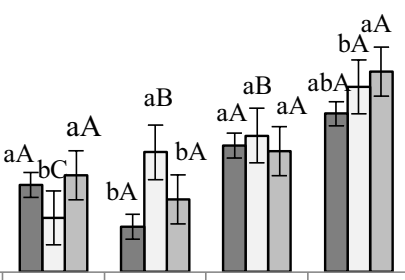

D.

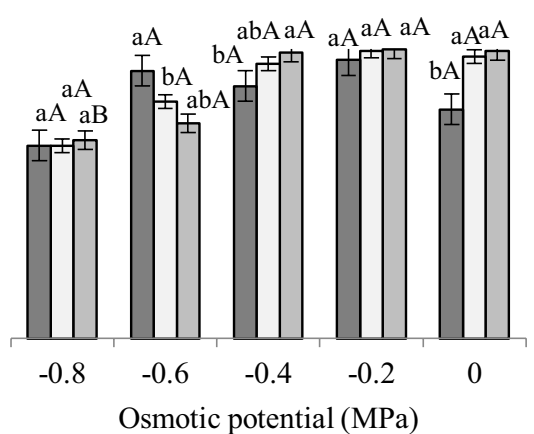

B.

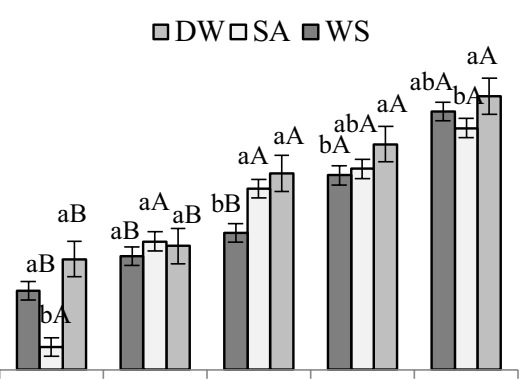

E.

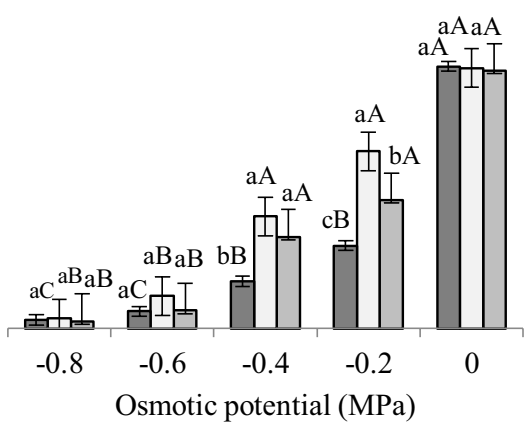

C.

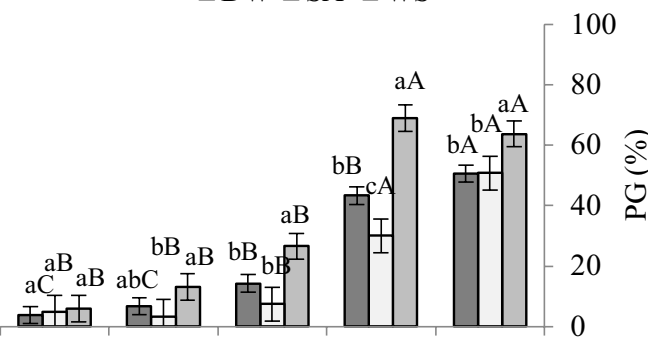

F.

'LAG-Pretinha'

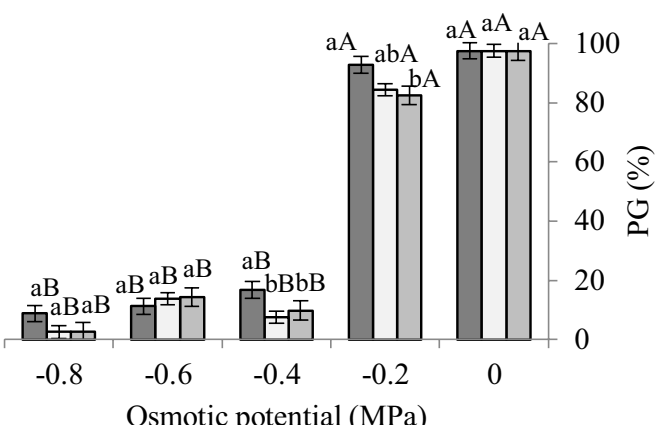

Columns with the same lowercase letter at each potential do not differ between seed treatments and columns with the same uppercase letter do not differ between potentials in each seed treatment (Tukey, $\mathrm{p} \leq$ 0.05); DW - Soaking in distilled water; SA - Soaking in salicylic acid; WS - Without soaking; Vertical bars represent the standard error of the mean

Figure 1. Percentage of germination (PG) of sesame genotypes under different osmotic potentials and pre-treatment of seeds 
For 'LAG-Branquinha', at the potentials of -0.2 and -0.4 $\mathrm{MPa}$, there was difference in the means of GSI and the highest ones were observed in seeds treated with SA (5.1), compared with WS (Figure 2E). Water restriction can reduce PG and GSI always when it reduces the speed of metabolic and biochemical processes, which delays or inhibits seed germination (Pereira et al., 2012), a fact observed in the present study.

Shoot length (SL) was reduced in the genotypes due to the drought stress, except in 'CNPA-G4', regardless of the seed treatment, and in 'CNPA-G3', in which the reduction occurred only in the treatment with SA (Figure 3). It must be highlighted that the reduction in seedling length occurs because the water restriction decreases the speed of physiological and biochemical processes, limiting the development (Abati et al., 2014).

There were expressive values of SL in the genotypes 'BRS Seda' and 'CNPA-G2', and in 'BRS Seda' the difference was observed according to the seed soaking treatments. At the potential of $0.0 \mathrm{MPa}$, the mean was $6.6 \mathrm{~cm}$ in seedlings from seeds treated with SA, with decrease in SL of seedlings at the

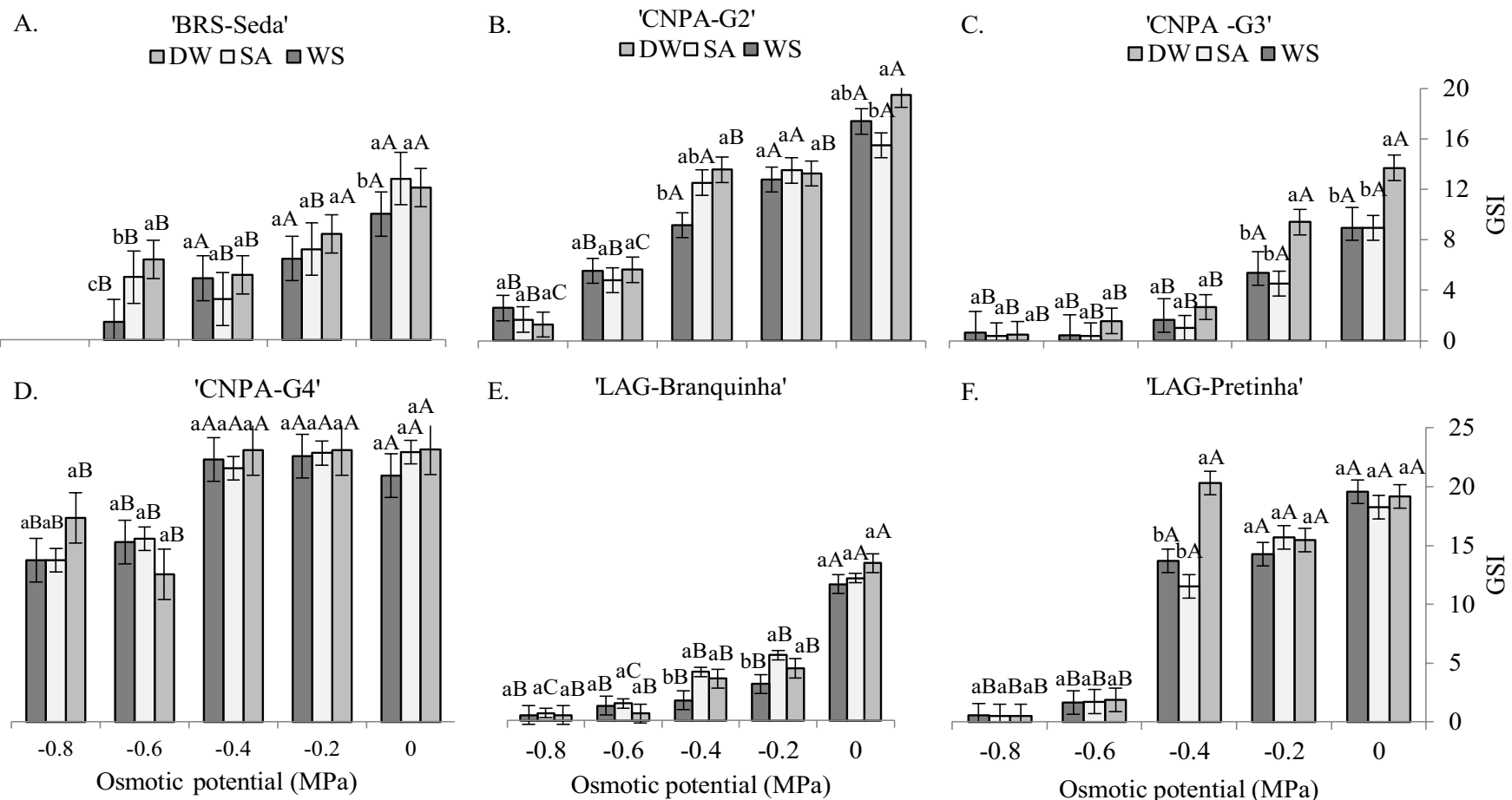

Columns with the same lowercase letter at each potential do not differ between seed treatments and columns with the same uppercase letter do not differ between potentials in each seed treatment (Tukey, $\mathrm{p} \leq$ 0.05); DW - Soaking in distilled water; SA - Soaking in salicylic acid; WS - Without soaking; Vertical bars represent the standard error of the mean

Figure 2. Germination speed index (GSI) of sesame genotypes under different osmotic potentials and pre-treatment of seeds

A. 'BRS-Seda'
$\square$ DW $\square$ SA $\square$ WS
B.

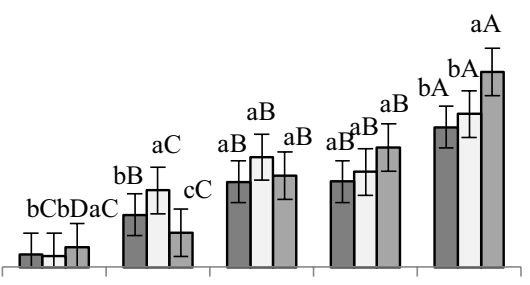

E.
'CNPA-G2'

$\square \mathrm{DW} \square \mathrm{SA} \square \mathrm{WS}$
C.

'CNPA-G3'

$\square$ DW $\square$ SA $\square$ WS

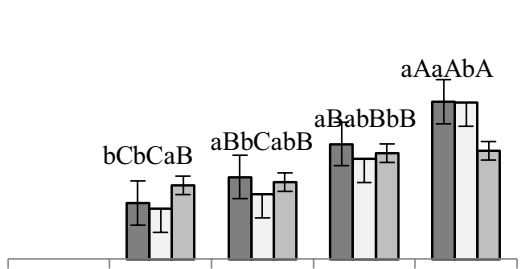

D.

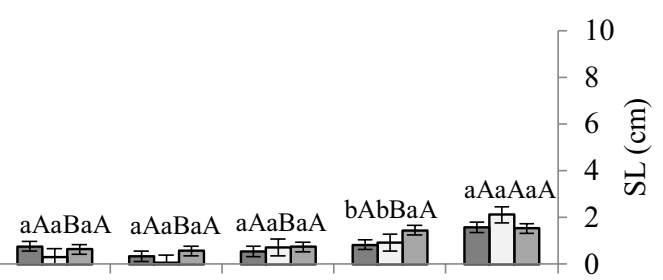

F.

'LAG-Pretinha'
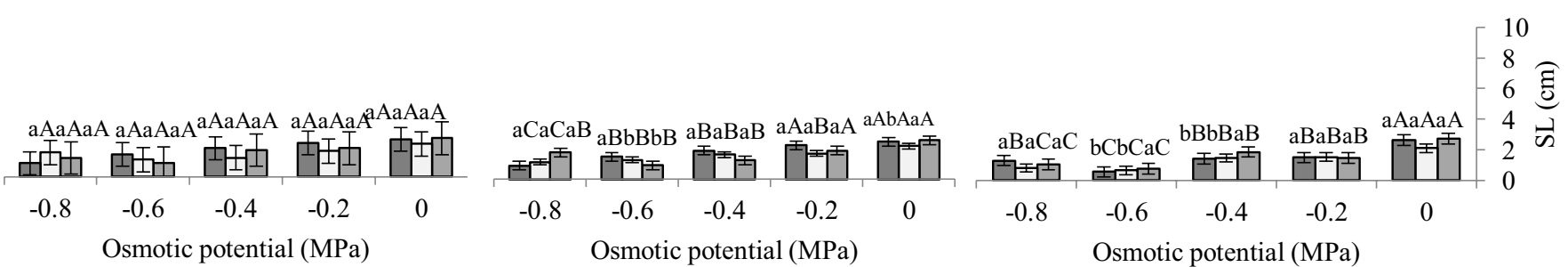

Osmotic potential (MPa)

Columns with the same lowercase letter at each potential do not differ between seed treatments and columns with the same uppercase letter do not differ between potentials in each seed treatment (Tukey, $p \leq 0.05$ ); DW - Soaking in distilled water; SA - Soaking in salicylic acid; WS - Without soaking; Vertical bars represent the standard error of the mean

Figure 3. Shoot length (SL) in sesame seedlings under different osmotic potentials and pre-treatments of seeds 
lowest potentials (Figure 3A). It should be pointed out that, in 'CNPA-G2' (Figure 3B), the SA promoted increase in seedling shoots at the potentials of -0.6 and $-0.4 \mathrm{MPa}$, although in the latter case there was no statistical difference comparing WS and DW.

In the line 'LAG-Pretinha' (Figure 3F), there was difference only at the potentials of -0.4 and $-0.6 \mathrm{MPa}$, with the highest means ( 1.86 and $0.75 \mathrm{~cm}$, respectively) in seedlings whose seeds were soaked in distilled water; however, there was reduction in SL at all negative osmotic potentials in this genotype. The materials cited above have characteristics of lower growth; 'CNPA-G4' has early cycle and medium size; 'LAG-Branquinha' has intermediate cycle and medium size and 'LAG-Pretinha' has intermediate cycle and small size (Arriel et al., 2009).

Regarding the antioxidant enzyme catalase, in the genotype 'BRS Seda' (Figure 4A), there was difference between the means with respect to the seed treatments and at the potentials. At the potential of $-0.2 \mathrm{MPa}$, in SA, CAT activity was $0.00708 \mathrm{mmol}$ of $\mathrm{H}_{2} \mathrm{O}_{2} \mathrm{~g}^{-1} \mathrm{MF} \mathrm{min}-1$ and, at $-0.4 \mathrm{MPa}$, it was $0.00591 \mathrm{mmol}$ of $\mathrm{H}_{2} \mathrm{O}_{2} \mathrm{~g}^{-1} \mathrm{MF} \mathrm{min}{ }^{-1}$, respectively.

The result for 'CNPA-G2' was similar to that of 'BRS Seda' (Figure $4 \mathrm{~B}$ ), in which, at the potentials of -0.2 and $-0.4 \mathrm{MPa}$, the soaking in SA stood out in the increase of CAT activity. In addition, at the potential of $-0.6 \mathrm{MPa}$, the highest mean was observed in seeds without soaking, justifying the lack of action of SA at higher levels of stress.

There was a trend of increase in CAT activity due to the reduction in the osmotic potential of the substrate for 'CNPA-G4' (Figure 4D), especially in the seed soaking treatments, making evident that, in this genotype, the soaking caused increase in the amount of the enzyme under drought stress conditions. In the genotype 'LAG-Branquinha' (Figure $4 \mathrm{E}$ ), there was also an increase in CAT activity with the reduction in the osmotic potentials, except at the potential of $-0.8 \mathrm{MPa}$.
A.
'BRS-Seda' 口DW $\square$ SA $\square$ WS
B.
'CNPA-G2' $\square \mathrm{DW} \square \mathrm{SA} \square \mathrm{WS}$

Pereira et al. (2012) report variation in CAT activity as a function of the duration and intensity of the drought stress and increment in its activity under moderate stress; however, as the stress becomes more severe, this behavior is inverted, as observed at the lowest osmotic potentials ( -0.6 and -0.8 $\mathrm{MPa}$ ) in 'BRS Seda' and 'CNPA-G2' (Figures 4A and 4B). Kadkhodaie et al. (2013) identified increase in CAT activity in sesame genotypes sensitive, intermediate and resistant to drought, indicating that the capacity of CAT to degrade $\mathrm{H}_{2} \mathrm{O}_{2}$ was maintained during severe drought stress, probably because sesame is a drought-tolerant species, although a constant behavior between genotypes and of the seed treatments was not observed in the present study.

Figure 5 shows variation in the activity of the antioxidant enzyme superoxide dismutase (SOD) in sesame seedlings as a function of the different osmotic potentials and seed treatments. There is a trend for higher activity of this enzyme in the genotypes 'CNPA-G2', 'CNPA-G4' and 'LAG-Pretinha' (Figures 5B, 5D and 5F, respectively). 'CNPA-G2' (Figure $5 B$ ) exhibited high SOD activity and the best response with seed soaking in SA, with superior results at the most negative potentials (-0.6 and $-0.8 \mathrm{MPa})$, similar to 'LAG-Pretinha', which showed best result with $\mathrm{SA}$ at the potential of $-0.8 \mathrm{MPa}$ (Figure 5F).

In the genotype 'LAG-Branquinha' (Figure 5E), the activity of the enzyme was low at all potentials, but there were increments in SOD activity at the first two levels of drought stress $(-0.2$ and $-0.4 \mathrm{MPa})$, equal to 50 and $100 \%$ in relation to the control, and decrease at the subsequent potentials, indicating that the antioxidant system is also not effective at high stress levels.

SOD activity can be required, even in normal situations, to dismutate reactive oxygen species evolved in the metabolism

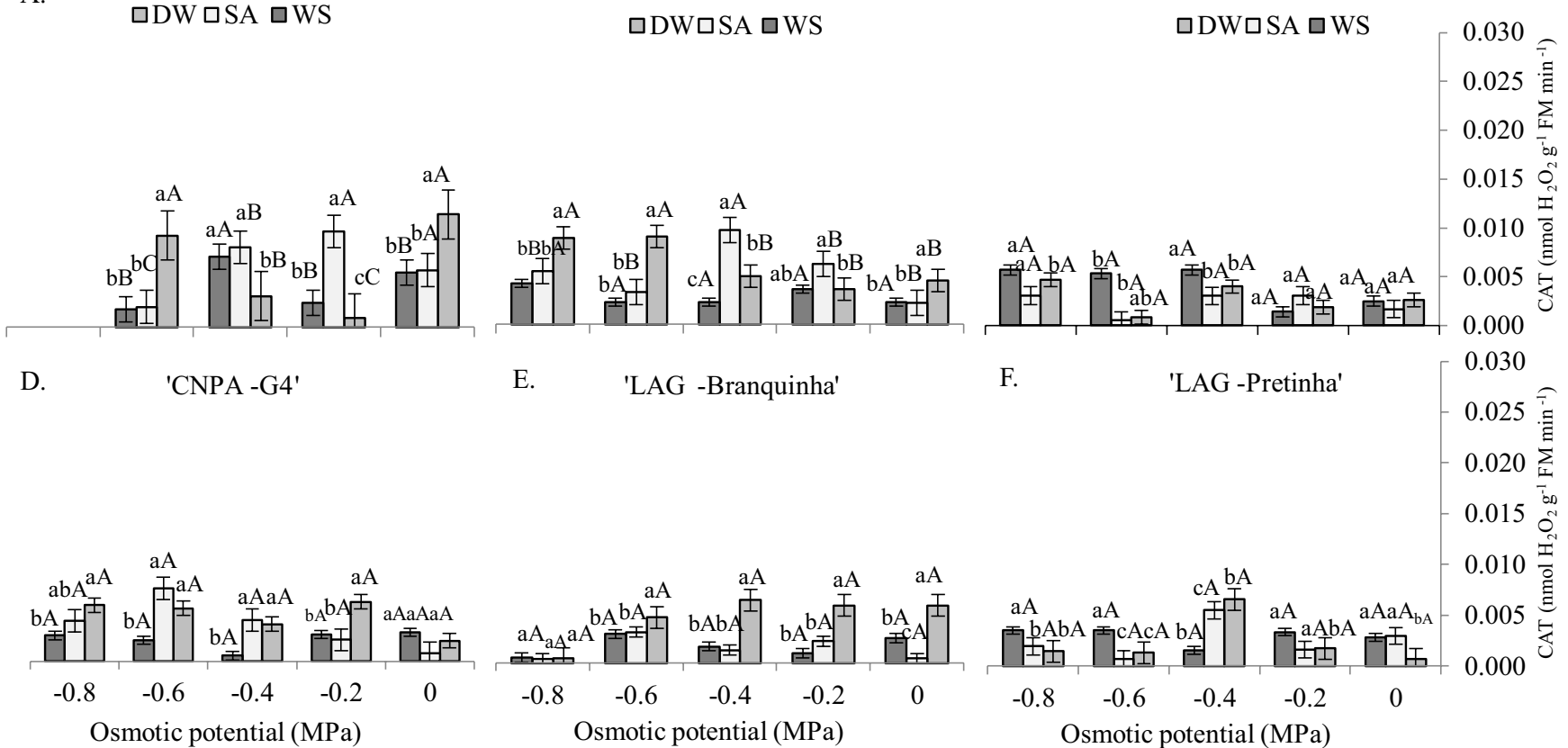

Columns with the same lowercase letter at each potential do not differ between seed treatments and columns with the same uppercase letter do not differ between potentials in each seed treatment (Tukey, $p \leq 0.05$ ); DW - Soaking in distilled water; SA - Soaking in salicylic acid; WS - Without soaking; Vertical bars represent the standard error of the mean

Figure 4 . Catalase activity (CAT) in sesame seedlings under different osmotic potentials and pre-treatments of seeds 
A.

'BRS -Seda' $\square \mathrm{DW} \square \mathrm{SA} \quad \square \mathrm{WS}$

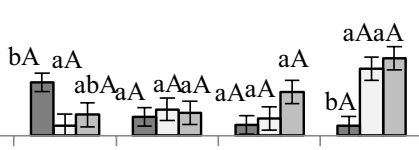

D.

$$
\text { 'CNPA -G4' }
$$

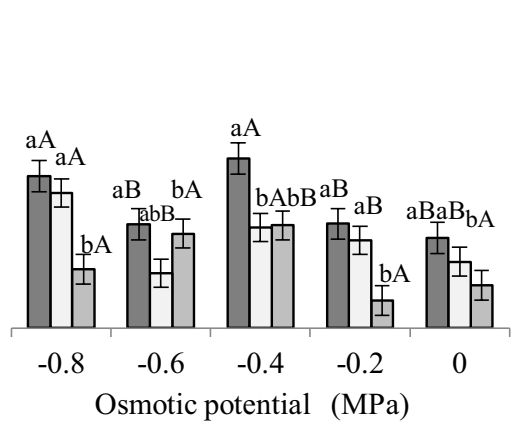

B.

'CNPA-G2'
$\square D W \square$ SA $\square$ WS

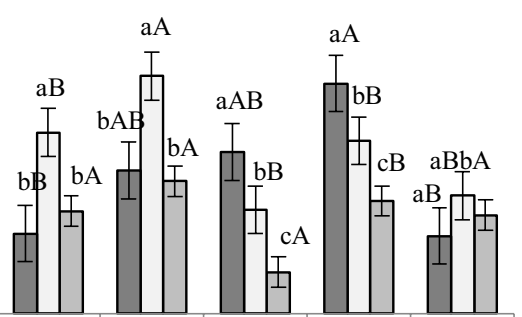

E.

E. 'LAG -Branquinha'
C.

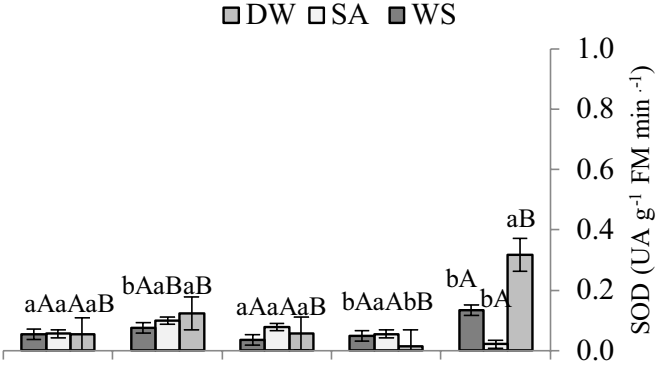

F.
'CNPA -G3' $\square \mathrm{DW} \square \mathrm{SA} \square \mathrm{WS}$
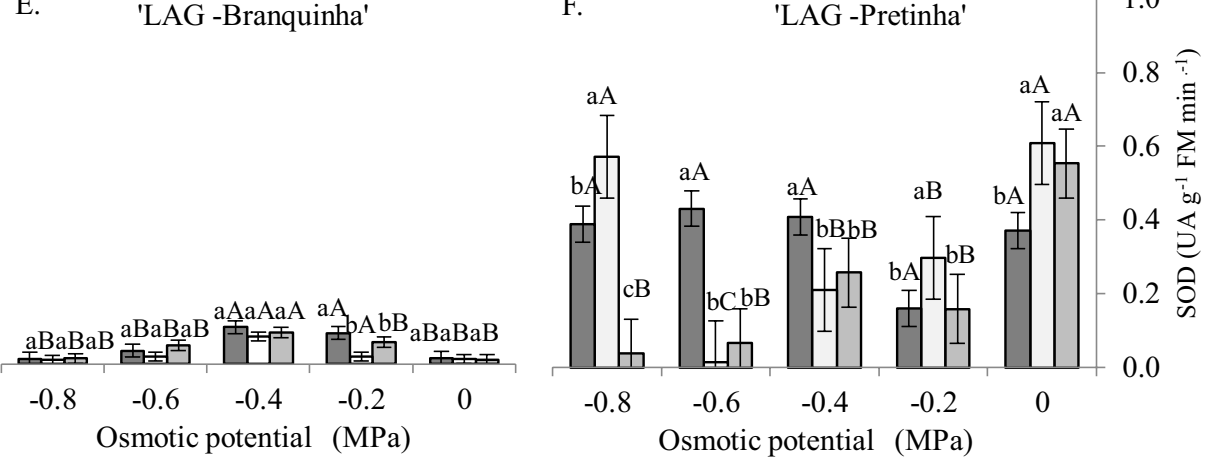

Columns with the same lowercase letter at each potential do not differ between seed treatments and columns with the same uppercase letter do not differ between potentials in each seed treatment (Tukey, $\mathrm{p} \leq 0.05$ ); DW - Soaking in distilled water; SA - Soaking in salicylic acid; WS - Without soaking; Vertical bars represent the standard error of the mean

Figure 5. Superoxide dismutase activity (SOD) in sesame seedlings under different osmotic potentials and pre-treatment of seeds

of sugars in the mitochondria, being necessary for the use of SOD as biochemical marker of parameters of the activity of the enzyme in normal environments (Coscolin et al., 2011).

\section{Conclusions}

1. The genotype CNPA-G4 has high capacity of tolerance to drought stress in the germination stage.

2. Water deficit promoted alterations in the antioxidant activity of the enzymes in sesame seedlings, with high CAT activity in 'BRS Seda' and 'CNPA-G2', and high SOD activity in 'CNPA-G2', 'CNPA-G4' and 'LAG-Pretinha'.

3. The salicylic acid at $10^{-5} \mathrm{M}$ induced tolerance to drought stress in sesame, and it is necessary to test other concentrations and forms of application for the crop.

\section{Literature Cited}

Abati, J.; Brzezinski, C. R.; Zucareli, C.; Henning, F. A.; Alves, V. F.N.; Garcia, V. V. Qualidade fisiológica de sementes de trigo tratadas com biorregulador em condições de restrição hídrica. Informativo ABRATES, v.24, p.32-36, 2014.

Anderson, M. D.; Prasad, T. K.; Stewart, C. R. Changes in isozyme profiles of catalase, peroxidase, and glutathione reductase during acclimation to chilling in mesocotylus of maize seedlings. Plant Physiology, v.109, p.1247-1257, 1995. https://doi.org/10.1104/ pp.109.4.1247

Arriel, N. H. C.; Beltrão, N. E. de M.; Firmino, P. T. Gergelim: O produtor pergunta, a Embrapa responde. Brasília: Embrapa Informação Tecnológica; Campina Grande: Embrapa Algodão, 2009. 209p. Coleção 500 Perguntas 500 Respostas
Beers Júnior, R. F.; Sizer, I. W. A spectrophotometric method for measuring the breakdown of hydrogen peroxide by catalase. Journal of Biological Chemistry, v.195, p.133-140, 1952.

Bezerra, S. A.; Dantas Neto, J. D.; Azevedo, C. A. V. de; Silva, M. B. R. S. e; Silva, M. M. da. Produção do gergelim cultivado sob condições de estresse hídrico e diferentes doses de adubação. Engenharia Ambiental, v.7, p.156-165, 2010.

Brasil. Ministério da Agricultura, Pecuária e Abastecimento. Regras para análise de sementes. Brasília: MAPA/ACS, 2009. 399p.

Carvalho, P. R.; Machado Neto, N. B.; Custódio, C. C. Ácido salicílico em sementes de calêndula (Calendula officinalis L.) sob diferentes estresses. Revista Brasileira de Sementes, v.29, p.114-124, 2007. https://doi.org/10.1590/S0101-31222007000100016

Coscolin, R. B. D. S.; Broetto, F.; Marchese, J. A.; Campohermoso, M. C.; Paladini, M. V. Effects of hydric deficiency on gas exchange parameters and metabolism of Eucalyptus grandis clones. Brazilian Journal of Plant Physiology, v.23, p.255-262, 2011. https:/doi. org/10.1590/s1677-04202011000400002

Dousseau, S.; Alvarenga, A. A. D.; Arantes, L. O.; Oliveira, D. M.; Nery, F. C. Germinação de sementes de tanchagem (Plantago tomentosa Lam.): influência da temperatura, luz e substrato. Ciência e Agrotecnologia, v.41, p.664-670, 2008. https://doi.org/10.1590/ s1413-70542008000200014

Giannopolitis, C. N.; Ries, S. K. Superoxide dismutases occurrence in higher plants. Plant Physiology, v.59, p.309-314, 1977. https:// doi.org/10.1104/pp.59.2.309

Kadkhodaie, A.; Razmjoo, J.; Zahedi, M. Peroxidase, Ascorbate peroxidase and catalase activities in drought sensitive, intermediate and resistance sesame (Sesamum indicum L.) genotypes. International Journal of Agronomy and Plant Production, v.4, p.3012-3021, 2013. 
Maguire, J. D. Speed of germination-aid in selection and evaluation for seedlig emergence and vigor. Crop Science, v.2, p.176-177, 1962. https://doi.org/10.2135/cropsci1962.0011183X000200020033x

Michel, B. E.; Kaufmann, M. R. The osmotic potential of polyethylene glycol 6000. Plant Physiology, v.51, p.914-916, 1973. https://doi. org/10.1104/pp.51.5.914

Noreen, S.; Ashraf, M.; Hussain M.; Jamil, A. Exogenous application of salicilic acid enhances antioxidative capacity in salt stressed sunflower (Helianthus annuus L.) plants. Pakistan Journal of Botany, v.41, p.473-479, 2009.
Pereira, W. P.; Melo Filho, P. A.; Albuquerque, M. B.; Nogueira, R. J. M. C.; Santos, R. C. Mudanças bioquímicas em genótipos de amendoim submetidos a déficit hídrico moderado. Revista Ciência Agronômica, v.43, p.766-773, 2012. https://doi. org/10.1590/S1806-66902012000400019

Silva, T. C. F. S.; Silva, R. C. B.; Silva, J. E. S. B.; Santos, R. S.; Aragão, C. A.; Dantas, B. F. Germinação de sementes de melancia sob diferentes métodos de tratamento com reguladores vegetais. Scientia Plena, v.10, p.1-15, 2014. 